\title{
Metaphysical Freedom. From Albert the Great to Berthold of Moosburg
}

\author{
Wouter Goris \\ Rheinische Friedrich-Wilhelms-Universität Bonn
}

1. When Albert the Great sets out to define "freedom" in the first book of his commentary on the De causis, he fishes in murky water by engaging with philosophical traditions that are only partly transparent to him.

"Freedom", the first concept in the series libertas - voluntas - omnipotentia discussed here, is assigned to the first principle in five steps. First, Albert discusses Aristotle's explanation of "what is free" as a causa sui in the Metaphysics (A1-4 in the appendix). Second, he claims that, since freedom is said in four modes - namely, as negating necessity by obligation, coaction, inevitability, and position - the first principle is free according to all of these modes $\left(\mathrm{A}_{5}-12\right)$. Third, he relates the opposed view, which denies freedom to the first principle, in order to safeguard it from imperfection (A13-17). Fourth, while answering to these objections, Albert shows that the first principle acts freely, not by necessity (A18-22). Finally, he interprets the freedom of the first principle according to the "richness" with which the Platonic tradition invests it (A23-24).

Surely, Albert was not only aware of, but also familiar with, the philosophical traditions that are mobilized by the opposed view. But it is no less certain that Albert could not fully appreciate or see through the complex process of transmission that connects Aristotle's definition of freedom in the Metaphysics with the Liber de causis, which Albert regards as the complement to Aristotle's philosophical theology.

In fact, Aristotle's definition of "the free" as causa sui was the model for Plotinus' Enneads vi.8, which describes the freedom of the absolute as "what wills its own being". Proclus, however, who objected that Aristotle's definition of "the free" as causa sui applies primarily to nous, denied it to the absolute One-Good. The concept of freedom is absent in the Elements of Theology, with the concepts of the self-sufficient (autarkes) and especially the self-constituted (authupostaton) coming as close to freedom as it gets. If, therefore, the author of the Liber de causis reproduces the notion of a causa sui ipsius, he seems to 
remain loyal to the Aristotelian tradition at the point at which he, in fact, deviates from his direct source, the Elements of Theology. ${ }^{1}$

This constellation is of interest when we compare Albert's discussion of the freedom of the first principle in his De causis-commentary to its literal reception, mediated by the De summo bono of Ulrich of Strassburg, in the commentary on the Elements of Theology by Berthold of Moosburg.

In these three authors, two opposite hermeneutical strategies clash: Albert's synthesis of the Aristotelian and the Neoplatonic traditions, in continuity with the Porphyrian tradition of "the harmony of Plato and Aristotle", on the one hand, and, on the other hand, Berthold's antithesis of these traditions, which follows the path first opened by Aquinas and his exposure of the pseudoAristotelian Liber de causis as, in fact, adapting and abridging the Elements of Theology.

Several questions of a heuristic nature arise here. How does Berthold compensate for Albert's reliance on Aristotle, in the light of his antithetical approach? And how does he account for the freedom of the first principle at all in his commentary, given the absence of the concept in the Elements of Theology?

2. Before engaging with the texts in a more direct way, I would first like to emphasise Albert's contribution to an articulation of a Platonic concept of absolute freedom - for that is what he does here, malgré soi - by invoking Albert's simultaneous endorsement of the Aristotelian conception of freedom as "freedom of choice". (Clearly, the use of historiographical categories like "Platonic" and "Aristotelian" reaches its true limits when we oppose the "freedom of choice" in the Nicomachean Ethics to the conception of freedom in Aristotle's Metaphysics, which we would label "Platonic". Perhaps it is more appropriate, therefore, to speak of metaphysical and ethical freedom instead. What is important is the difference between the two.)

Metaphysical freedom, the freedom of the Absolute, can be distinguished from ethical freedom, the freedom of choice associated with human agency. In fact, the freedom of the Absolute dialectically sublates the very necessity that

1 See W. Beierwaltes, "Pronoia und Freiheit in der Philosophie des Proklos", in Freiburger Zeitschrift für Philosophie und Theologie 24(1977), p. 88-111; W. Beierwaltes, "Proklos' Theorie des Authypostaton und seine Kritik an Plotins Konzept einer causa sui", in Das wahre Selbst (Frankfurt am Main: Klostermann, 2001), p. 160-181; Th. Kobusch, "Bedingte Selbstverursachung. Zu einem Grundmotiv der neuplatonischen Tradition", in Th. Kobusch, B. Mojsisch, O.F. Summerell (eds), Selbst - Singularität - Subjektivität. Vom Neuplatonismus zum Deutschen Idealismus (Amsterdam / Philadelphia: Grüner, 2002), p. 155-173. 
is excluded by the notion of freedom of choice as indifference. Their opposition shapes the history of philosophy, where the Neoplatonic affirmation of the absolute freedom of the Good is metaphysical at the expense of any ethics conceived as an independent discipline based on practical reason, and where, inversely, Aristotle is understood as an advocate of an ethical conception of freedom and the human good, at the expense of a metaphysical conception of the Good, which, if it existed, would be irrelevant for human agency. ${ }^{2}$

This opposition, which can only be sketched here, must be addressed in order to appreciate Albert's strategy in defending the freedom of the first principle. ${ }^{3}$ For when Albert takes issue with the position that declares the first principle to act by necessity, his discourse actually enacts the dialectical mediation between freedom and necessity, which we have just mentioned.

Indeed, Albert concedes that the freedom that is opposed to necessity is an imperfection from which the first principle must be preserved, while insisting that this is not the only conceivable kind of freedom. What results is a conception of absolute freedom that is no longer opposed to necessity and that is acknowledged to be incompatible with the conception of ethical freedom that Albert endorses elsewhere in his works, but is denied here, due to its imperfection, to the first principle. The real issue, it seems, then, is the unity of the concept of freedom in Albert.

3. Turning to the text of Albert, I postpone for now the discussion of the four modes according to which freedom is applied to the first principle. Albert introduces Aristotle's explanation of "the free" as causa sui in the Metaphysics, in order to prove the general claim that the first principle is in every way free to

2 See W. Goris, "Metaphysik der Freiheit", in J. Müller, Ch. Rode (eds), Freiheit und Geschichte. Festschrift für Theo Kobusch zum 7o. Geburtstag (Münster: Aschendorff, 2018), p. 229-250; W. Goris, "Die Freiheit und das Gute", in C. Böhr (ed.), Metaphysik. Von einem unabweislichen Bedürfnis der menschlichen Vernunft. Rémi Brague zu Ehren (Wiesbaden: Springer VS, 2020), p. 373-39o; J. Halfwassen, "Freiheit als Transzendenz. Zur Freiheit des Absoluten bei Schelling und Plotin”, in J.-M. Narbonne, A. Reckermann (eds), Pensées de l'Un dans l'histoire de la philosophie. Études en hommage au Professeur Werner Beierwaltes (Paris: Vrin, 2004), p. 459-481. For the later tradition, see the excellent essay by Ch. Krijnen, "Die Wirklichkeit der Freiheit begreifen. Hegels Begriff von Sittlichkeit als Voraussetzung der Sittlichkeitskonzeption Kants", in Folia Philosophica 39(2018), p. 37-144.

3 For prior publications on the concept of freedom in Albert the Great, I refer the reader to H. Anzulewicz, "Das Phänomen des Schicksals und die Freiheit des Menschen nach Albertus Magnus", in J. Aertsen, K. Emery Jr., A. Speer (eds), Nach der Verurteilung von 1277. Philosophie und Theologie an der Universität von Paris im letzten Viertel des 13. Jahrhunderts. Studien und Texte (Berlin: De Gruyter, 2001), p. 507-534; E. Miteva, "I Want to Break Free. Albert the Great's Naturalistic Account of Freedom of Choice and its Limitations", in Bochumer Philosophisches Jahrbuch für Antike und Mittelalter 21(2018), p. 11-28. 
act. Before assessing the different modes according to which the first principle is free to act, this freedom itself first needs to be established.

The first principle is in every way free to act. For Aristotle says in the first book of the Metaphysics that "we call 'free' the one who acts on his own behalf" [causa sui: cause of itself]. Since, therefore, the first principle is in the highest sense on its own behalf (causa sui) in acting, it is the most free in action, and not just free, but even placed above freedom. For it has its "own power" (dominium) in its action. For the first is lord of all its acts. If now man is lord of his acts, since the cause of his acts is in him, all the more so the first of all is lord, who is for himself cause in every action. $\left(\mathrm{A}_{1}-4\right)$

The meaning of the text is clear from a comparison with Albert's commentary on the Metaphysics. ${ }^{4}$ Our point of reference is not the commentary on the first book of the Metaphysics, from which the quotation of Aristotle is taken, and in which Albert discusses freedom in relation to science and the liberal arts. ${ }^{5}$ Rather, in the commentary on Metaphysics Lambda, where Albert comments on the notion of prote ousia as pure act, he reproduces the whole discussion on the first principle as necesse esse that acts by its own essence, without thereby losing its freedom, since it is free in the sense of what is causa sui. The connection with the De causis-commentary is manifest in the digression that Albert adds to explain that the first substance is "above every name" (super omne nomen).

We may notice, moreover, that Albert introduces a slight twist in his explanation of Aristotle's conception of freedom. The first principle is "the freest" and not just free, but "placed above freedom", which designates the transcendence proper to the first principle. The conclusion of the text discusses freedom as the largitas of magnificence, as the expression of self-sufficiency or autarky (see Liber de causis, prop. XIX $[\mathrm{xx}]$ ).

4. Referring to previous deliberations, Albert introduces the position that contradicts his conclusion that the first principle is "the freest" both in itself and in its actions since it does not depend on any other cause and thus is free from all necessity.

4 Albert the Great, Metaphysica, ed. B. Geyer, Editio Coloniensis 16/1-2 (Münster i.W.: Aschendorff, 196o-1964), lib. XI, tr. 2, c. 2, p. 484, l. 48-p. 485, l. 31.

5 Albert the Great, Metaphysica, lib. I, tr. 2, c. 7, p. 24, l. 13-92. 
In the five arguments contra, it is argued that it is proper to the first principle to act by necessity, and not freely. The first two arguments rely on the concept of the necesse esse, which acts per essentiam, both of which seem to exclude freedom. The first argument is as follows:

Against this, however, some try to To these objections, however, and counter by what was said before. It others like it one can easily respond, was said, namely, that the first is nec- namely, that the first is in every way essary being totally and in every way. necessary being. But for this reason And what is necessary in every way, freedom is not removed from it. For in no way seems to be free. $\left(\mathrm{A}_{13}\right)$ necessity, which is by dependence on another cause, is removed from the first. But for that reason freedom is not removed, such that in it is the cause of its action. (A18)

The reference to "what was said before" indicates chapters 9-11 of the first treatise in this first book, where the first principle is established as necesse esse; the Cologne edition has shown in detail how this passage in Albert's text is elaborated upon the abridgement of Avicennian doctrine in the Metaphysica Algazelis. The arguments contesting the freedom of the first principle here are based, therefore, on Avicenna. ${ }^{6}$

In his answer, Albert concedes that the first principle is necesse esse, but denies that such necessity annuls freedom. It is perfectly reasonable, he affirms here with the entire Platonic tradition, to deny necessity to the first principle, so as to remove any dependence upon other causes, while affirming its freedom in the sense of what necessitates itself.

The last three arguments $\left(\mathrm{Al}_{1}{ }^{-16}\right)$ articulate a conception of freedom as the disposition "to act or not to act", which, if posited in the first principle, would introduce change into what is immutable, withhold the perfection of everlasting action from it, and falsely attribute something to the higher realm which implies an imperfection in the lower realms. ${ }^{7}$ The key to solving these objections is provided by the answer to the third argument:

6 See Albert the Great, De causis et processu universitatis a prima causa, ed. W. Fauser, Editio Coloniensis 17/2 (Münster i.W.: Aschendorff, 1993), lib. I, tr. 1, c. 9, p. 17, l. 33-p. 18, l. 4 O.

7 In the Summa theologiae, Albert attributes this conception of freedom to Avicenna: in potestate suae libertatis habet agere et non agere et agere hoc et contrarium huius. See Albert the Great, Summa theologiae sive de mirabili scientia Dei. Libri I, pars I. Quaestiones 1-50A, ed. D. Siedler, Editio Coloniensis 34/1 (Münster i.W.: Aschendorff, 1978), pars I, tr. 2, q. 3, c. 2, p. 3o, 
Furthermore, what is free is that in Furthermore, by that which is said, which there is "to act and not to act". that there is not "to act and not to act" If it is said, however, that in the first in it, nothing is proved. For this is said there is "to act and not to act", one in a twofold way. The absence of "to act must concede that the first is subject to variation. This, however, is impossible, since it is totally unchangeable, as was proved before. Therefore, there is not "to act and not to act" in it. It is necessary, therefore, that it acts. And thus it is subject to necessity and not to freedom. (A15) and not to act" in something can be the result of compulsion to the one and the impossibility of the other. In the other way, it can be the result of freedom to the one and the other. But because it is better to be the one than the other, therefore it does not turn from the one to the other - just as in the chaste there is acting chastely and not chastely, and in the generous to give and not to give. But because it is better to act chastely and to give generously than to act unchastely and to hold back greedily, therefore the chaste and the generous does not turn to the opposite of its action. And thus "to act and not to act" is in the first indeed, but it cannot not act, since it is better to send out goodness than to hold it back, and "it is impossible to attribute anything in the least unbecoming to it". ${ }^{8}$ (A20)

The freedom "to act and not to act" is denied incorrectly to the first principle by the objection, if its denial is taken in the sense of being forced to do something because it is impossible to do the opposite. Clearly, the first principle is free in this sense, for the contrary would conflict with its omnipotence. But necessity can also be taken in the sense of having the ability "to act and not to act", while preferring the one over the other because of its perceived goodness. In this sense, Albert says, the first principle is free not to act, while acting necessarily in conformity to its own goodness.

More urgent at present than a consideration of Albert's replies to the fourth and fifth objections, which also follow this strategy, is the clarification of the

1. 11-15. One notes the differentiation here between executio actus (agere et non agere) and specificatio actus (agere hoc et contrarium huius).

8 The quotation is from Anselm, Cur Deus homo, lib. I, c. 10. 
type of necessity that the freedom of the first principle negates (see A4-12). The necessity to act that is attributed to the first principle is not the necessity which determines nature to one action; this type of necessity, in the form of an obligatio ad unum, is clearly opposed to the freedom of the first principle. But the necessity attributed to the first principle differs less evidently from the fourth type of necessity, that of position (in the sense of "presupposition"), which corresponds to the final cause. ${ }^{9}$ Albert refers to a passage in the Nicomachean Ethics on the unity of the virtues, where Aristotle (cf. NE VI.13, 1145a4-6) explains that choice requires both virtue and practical wisdom, which can be distinguished in terms of what determines the end and what makes us do the things that lead to the end:

For a goal being posited, if one has to attain this goal, it is necessary to attend to what is necessary to attain the goal. As Aristotle says, "in order to have moral virtue it is necessary to have prudence, because prudence inquires and chooses that which leads to the moral goal of virtue, since moral virtue tends only as nature to the goal, without considering that which leads to the execution of its goal". (A10)

It seems to me that this relation is very akin to the necessity to act, if acting is perceived as to do what is good, which is granted to the first principle in the response to the third objection.

My point, however, is not to challenge the consistency of Albert's remarks, but to check the definition of freedom as what can both act and not act. Freedom is defined here exclusively in relation to the executio actus, and not to the specificatio actus. That the first principle is free not to act, yet is bound to act by its goodness, might be interpreted as an evasive strategy. But is not the

9 See Albert the Great, Summa theologiae, lib. I, tr. 7, q. 3o, c. 3, p. 237, l. 33-42, where Albert negates the first three types of necessity to God, while accepting the fourth: Dicitur quarto modo necessitas secundum causam finalem, quam Boethius vocat necessitatem suppositionis, secundum quam dicimus: si femina honesta esse debeat, necesse est castam esse [...]. Et hoc modo dicimus, quod pater necessitate genuit filium, quia si summum bonum esse debeat, necesse est, quod summa et perfecta diffusione seipsum diffundat et communicet. See also the questions on liberum arbitrium: Albert the Great, In II Sententiarum, ed. A. Borgnet, vol. 27 (Paris: Vivès, 1894), d. 3, A, a. 7, p. 72b; Albert the Great, De homine, eds H. Anzulewicz, J. Söder, Editio Coloniensis 27/2 (Münster i.W.: Aschendorff, 2008), a. 3.4.1, p. 519-p. 521. In the latter text, Albert follows Anselm in distinguishing freedom from the flexibilitas in bonum et malum, which is based here on an objection from Aristotle: Praeterea, in primo Metaphysicae habetur quod dicimus hominem liberum, quia causa sui est tantum; ergo videtur quod libertas sic deberet determinari secundum rationem illam, scilicet quod libertas arbitrii in hoc est quod ipsum causa sui est in actibus (p. 520). 
real problem the question that Albert dodges successfully, that is, whether the first principle is free to do something or its very opposite?

5. We may conclude that Albert introduces necessity into the concept of freedom that he attributes to the first principle, and thus subscribes to the Platonic tradition of absolute freedom that originates in Enneads vi.8. Albert subsequently builds on this tradition when he derives from the freedom of the first principle that it has will and is omnipotent, since its freedom requires neither deliberation, as we have seen, nor an explicit appetite for things absent. ${ }^{10}$

Against this, however, some object subtly by saying that everything that has in itself the principle of its action and that is totally free, is willing. But the first has in the highest sense in itself the principle of its action and is totally free. Therefore, the first is willing in the highest sense. ${ }^{11}$

The association of these quidam with the position of Plato, as well as the identification of the will as a free cause of its actions with Boethius sequens Platonem, ${ }^{12}$ makes clear that Albert has identified a Platonic conception of absolute freedom. This freedom is compatible with the freedom of choice that he relates to Aristotle only on the condition of removing the imperfection that is inherent to the freedom of choice.

6. Albert's careful, and perhaps even cautious, discussion on the freedom of the first principle is rearranged by his pupil Ulrich of Strassburg in De summo bono IV.1.4, which reproduces the same series of attributes: De primi principii libertate, voluntate et omnipotentia. Ulrich interprets Albert's approach as attributing three different concepts of freedom to the first principle. In his reconstruction, Ulrich imposes a hierarchy among these concepts.

The first concept is the freedom of dependency from a cause, which is proved by literal quotations from the second section in Albert's discussion. Ulrich recognizes the complexity in Albert, and even smooths out the text, when he characterizes the freedom of the first principle.

10 Albert the Great, De causis et processu universitatis, lib. I, tr. 3, c. 2, p. 37, l. 50-55.

11 Albert the Great, De causis et processu universitatis, lib. I, tr. 3, c. 2, p. 37, l. 26-30: Contra hoc autem quidam subtilissime obiciunt dicentes, quod omne quod in seipso habet suae actionis principium et omnino liberum est, volens est. Primum autem maxime in seipso habet suae actionis principium et omnino liberum est. Ergo primum maxime volens est. 
And this first principle is free both in itself and in its action. (B1)

That the first principle is free in itself follows from the compatibility of this freedom with the necessity of immutability, which Ulrich had already affirmed of the first principle. Hence, what was dialectically mediated in Albert, is in Ulrich transformed into a straightforward assertion.

The freedom of the first principle (haec libertas) is compatible with the necessity proper to it alone (haec necessitas), since it is causa sui. This freedom is compatible with the necessity of immutability, but not with the necessity of dependence on another cause, which is ruled out by the necessity of immutability.

Since Ulrich proceeds to show that there exists no genus of cause according to which the first principle is dependent and necessitated in its action, we can register two interesting deviations from Albert's text: Ulrich extends the discussion of "freedom from inevitability" with a reflection on the essences of things, and he omits the dimension of ethical freedom which fueled Albert's analysis of "the necessity of position" (B8 and 10).

A second type of freedom can be discerned in the freedom to act and not to act, which was the core of Albert's answer to objections $3-5$ and which Ulrich associates, silently quoting the Liber de causis, with the magnificence and selfsufficient generosity ascribed to the first principle by the Peripatetics (B24).

From this freedom Ulrich distinguishes a third type, which is the freedom of what is causa sui, and which he ascribes explicitly to Aristotle, to which a short summary of Albert's explanation is added (B25-26). Only the ascription of liberum and liberissimum remains; the libertati superpositum is removed.

We may conclude, therefore, that Ulrich does more than simply rearrange Albert's argument about the freedom of the first principle. Albert's argument is transformed into a hierarchy of three concepts of freedom. In this way, Ulrich stresses the compatibility of freedom and necessity. He also emphasizes their compatibility with the freedom to act and not to act. Finally, the Aristotelian concept of freedom, which was at the basis of Albert's approach and which still tacitly informs Ulrich's description of the first type of freedom, is reduced to a mere afterthought.

The conception of freedom that slowly starts to emerge in Ulrich, becomes fully manifest in Berthold of Moosburg's commentary on the Elements of Theology.

7. Berthold employs Ulrich's discussion of the freedom of the first principle in the commentary on Proposition 23 of the Elements of Theology: 
All that is unparticipated produces out of itself the participated; and all participated substances are linked by upward tension to existences not participated..$^{13}$

It is interesting to observe which passage Berthold selected to insert the discussion on freedom in his commentary. In Proposition 23, Proclus introduces the notion of the unparticipated as part of the triad $\dot{\alpha} \mu \varepsilon \theta \varepsilon \kappa \tau o v-\mu \varepsilon \tau \varepsilon \chi \chi^{\prime} \mu \varepsilon v o v-$ $\mu \varepsilon \tau \varepsilon$ ¿ $\bigcirc$ v (imparticipatum, participatum, participans) - a central triad in Proclus' philosophy. In establishing the hierarchy of the unparticipated, the participated, and the participating, Proclus first differentiates between the unparticipated and the participated, before projecting the hierarchy of the participated (superior) and the participating (inferior) upon the unparticipated (superior) and the participated (inferior) in Proposition 24. The differentiation between the unparticipated and the participated in Proclus responds to Plato's selfcriticism regarding the doctrine of participation in the Parmenides. Its mediation of immanence and transcendence is codified in Proposition 23. Since it would be derogatory to the perfection of the unparticipated if it were to remain ungenerative, the unparticipated must give something of itself; but since it is both common to all that can participate and identical for all, it must be prior to all and must be unparticipated.

Proclus here elaborates a structure that applies to the entire hierarchy that links the One, Intellect, Soul, and Nature. Following this reasoning, Berthold infers that "the unparticipated" applies to the One-Good as well. In his commentary, Berthold first identifies the possible referents of the term "the unparticipated" before specifying the meaning of the term in the proposition. It is at this stage that he deals with the very modes of freedom which Albert and Ulrich ascribed to the first principle. Berthold distinguishes three modes according to which imparticipatum is said: communiter, proprie, and magis proprie. The commonly accepted meaning applies to every intellectual nature, the proper meaning to every first and principal being of an order, and the most proper meaning to the One-Good alone, which has neither superiors nor inferiors to which it would be related by participation.

Proposition 23, Berthold observes, is concerned with imparticipatum taken in the second sense (proprie):

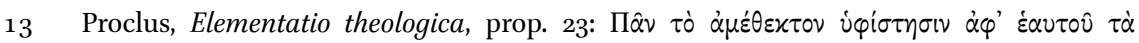

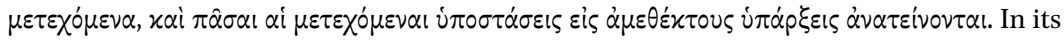
Latin translation: Omne imparticipatum instituit a se ipso participata, et omnes participatae hypostases ad imparticipatas essentias eriguntur. 
In the other way, namely in a proper sense, "unparticipated" refers to everything that is first and principally a being according to each order, total or partial, viz. that either is simply and absolutely first (the good and the one) or with respect to some determinate and partial order only (for example, the first virtue, the first being, and so on). What is such, is not partially taken [i.e., participatum as quasi partialiter captum, wG] from inferiors, since it is the most absolute and superperfect in its kind, which as such is "by itself" (sui gratia) and thus "being by itself" (sui ipsius ens), and this free from every mode of contraction, by which its kind is limited, as will be said immediately below. And thus it is before everything whatsoever that is contracted in its intention, as the truly separate and exempt, for the absolute is always prior and more eminent than the contracted; and thus it is called "unparticipated", that is not partially taken, either from the whole of its order simultaneously or from something of its order, since it is common to all and before all of which it is exempt. In this sense "unparticipated" is understood in the present proposition. ${ }^{14}$

The "unparticipated" applies to every maneries entium, and denotes the most absolute and perfect mode of being within each order, which is sui gratia and sui ipsius ens - that is, the unparticipated is free from all contraction and is transcendent, although it does not necessarily refer only the One-Good itself, which is unparticipated in the sense that "it has its own essence only from itself, since it does not depend from anything else" ("propriam essentiam non habeat nisi ex se, cum non pendeat ex alio").

8. Having established the referent of the term imparticipatum, Berthold proceeds to detail its meaning and defines the unparticipated in the following way:

14 Berthold of Moosburg, Expositio super Elementationem theologicam Procli. Propositiones 14-34, eds L. Sturlese, M.R. Pagnoni-Sturlese, B. Mojsisch (Hamburg: Meiner, 1986), 23A, p. 112, 1. 24-p. 113, l. 37: Alio modo, scilicet proprie, dicitur imparticipatum omne, quod est prime et principaliter ens secundum unumquemque ordinem, et hoc sive totalem sive partialem, hoc est sive sit simpliciter et absolute prime, puta bonum et unum, sive respectu alicuius determinati et partialis ordinis solum, puta prime virtus, prime ens et huiusmodi. Omne enim tale non est partialiter captum ab inferioribus, cum sit absolutissimum et superperfectissimum in sua manerie, quod inquantum huiusmodi est sui gratia et sic sui ipsius ens, et hoc liberum ab omni modo contractionis, quibus habet sua maneries limitari, ut statim infra dicetur. Et sic est ante omnia qualitercumque in sua intentione contracta sicut vere separatum et exemptum, cum semper absolutum prius et eminentius sit contracto; et sic dicitur imparticipatum, id est non partialiter captum, et hoc sive a toto suo ordine simul sive ab aliquo ipsius ordinis, cum sit commune omnium et ante omnia, a quibus est exemptum. Et sic accipitur in proposito elemento. 
Indeed, the unparticipated, such as it is taken here, according to its essential description, is (i.) a thing, (ii.) existing by itself, (iii.) having from itself and in itself a superplenitude of its own goodness or (iv.) of an intention by itself in whatsoever way originally instituted..$^{15}$

Before we focus on the second condition, "existing by itself", I want to make two remarks on the other aspects of this description, which aims to give a real definition (secundum quid rei) instead of a merely nominal one (secundum quid nominis).

First, Berthold comments on the concept of res with the remark:

In this description, "thing" is taken generically, not insofar as it derives grammatically from "I think, you think", but from "solidity", since the unparticipated is something solid in nature. ${ }^{16}$

Although this distinction between res a reor, reris and res a ratitudine is related in a privileged way to the first Quodlibet (1276) of Henry of Ghent, it is also found in Bonaventure and Aquinas. ${ }^{17}$ If I highlight this term, it is because it is indicative of the central place accorded to the idea of an essential order, both here and in the Avicennian tradition leading up to Scotus.

Secondly, the further elements - which entail a subdivision between the simpliciter imparticipabile, which is the first One and Good, and the imparticipabile in a determinate intention ${ }^{18}$ - refer back, as Berthold notes (sicut expositum est super 9), to the exposition on Proposition 9, about what is selfsufficient (autarkes) according to substance or operation - I will come back to this shortly.

As for the second condition of the imparticipatum mentioned already (sui ipsius existens), Berthold interprets this in terms of what is free both in itself and in its action, as he explains in agreement with Ulrich:

15 Berthold of Moosburg, Expositio, 23B, p. 113, 1. 59-61: Sane imparticipatum, prout hic sumitur, secundum quid rei est res sui ipsius existens habens a se ipsa et in se ipsa superplenitudinem propriae bonitatis seu intentionis a se qualitercumque originaliter institutae.

16 Berthold of Moosburg, Expositio, 23B, p. 113, 1. 62-64: In ista descriptione res accipitur pro genere, non prout grammatice descendit a reor, reris, sed a ratitudine, cum imparticipatum sit quid ratum in natura.

17 See P. Porro, "Res a reor, reris / res a ratitudine. Autour d'Henri de Gand", in I. Atucha, D. Calma, C. König-Pralong, I. Zavattero (eds), Mots médiévaux offerts à Ruedi Imbach (Porto / Turnhout: Fédération Internationale des Instituts d'Études Médiévales, 2011), p. $617-628$.

18 Berthold of Moosburg, Expositio super Elementationem theologicam Procli. Propositiones 160-183, eds U.R. Jeck, I.J. Tautz (Hamburg: Meiner, 2003), 163A, p. 24, l. $12-22$. 


\section{Ulrich}

Berthold

And this first principle is free both in itself and in its action. $(\mathrm{B1})$

I say, however, "existent by itself", in order that it is understood to be free both in itself and in its action. $(\mathrm{C} 1)$

What is free in itself is described by Berthold in accordance with Ulrich along the four modes of freedom, in which the necessary dependence from other causes is excluded (C6-11).

But whereas Ulrich related freedom in action to Albert's discussion of agere et non agere (B2O), Berthold insists on the notion of what acts per esse (C12) which was part of the formal or essential characteristic of freedom in Ulrich and Berthold alike.

\section{Ulrich}

\section{Berthold}

And this freedom is according to the Just like every unparticipated has freesimplicity by which something has a form, not as a part of itself - rather it is its essence and is its freedom and is whatever it has. For, indeed, it acts whatever it acts by its essence, and yet it acts freely, for its essence is its freedom and free will, and this freedom is in the first principle. And therefore the case of what acts by its essence, and the case of what acts naturally by the essence of its form, like fire necessarily burns and the like, are not the same (B9) dom in itself, insofar as it is "being by itself" and "for its own sake", in the same way it has freedom in action, since it acts by its being, and thus the action that remains in it is one with their essence. $\left(\mathrm{C}_{12}\right)$

And this is rooted in simplicity, either in all ways and absolutely or respectively. For thus each simple principle is its freedom, by which it is completely what it is, and completely acts what it acts, and yet it acts freely, since its essence is its freedom. (C9)

I take this to be the essence of what I call here a Platonic concept of freedom.

9. Now what about Aristotle? What happened to the Aristotelian definition of freedom, which was central for Albert and became a sort of appendix for Ulrich? It is eliminated by Berthold. And not only the reference to Aristotle 
has disappeared, the vocabulary itself is replaced: where Ulrich has causa sui, Berthold has gratia sui or sui ipsius existens. This is no mere coincidence. In fact, Berthold considers the concept of a causa sui to be self-refuting, as is clear from assertions like "illud esset causa sui ipsius, quod est impossibile" and the recurring reference in the Expositio to the eighth proposition of Nicholas of Amiens' De arte fidei, which asserts that nihil est causa sui. Here, we return to the commentary on Proposition 9 of Proclus, where Berthold explains the "sufficiens bonum as quod habet a se ipso et in se ipso plenitudinem propriae bonitatis". Berthold argues that a se ipso must be understood in respect to formal causality and not efficient causality:

But I say "by itself" formally, not efficiently, since by way of an efficient cause nothing begets itself in order to exist, according to Augustine. The author of De arte fidei alludes to this in prop. 3: "Nothing composed itself or brought itself into being," and prop. 8: "Nothing is cause of itself," although formally it both proceeds from itself and converts to itself. ${ }^{19}$

For Berthold, from the perspective of efficient causality, the notion of causa sui is self-contradictory. It can, however, be given an acceptable interpretation in terms of formal and essential causality: freedom is essential self-constitution.

\section{Appendix}

$\mathrm{A}=$ Albert the Great, De causis et processu universitatis a prima causa, ed. W. Fauser, Editio Coloniensis 17/2 (Münster i.W.: Aschendorff, 1993), lib. I, tr. 3, c. 1, p. 35, l. 10-p. 36, l. 6 o.

B = Ulrich of Strassburg, De summo bono. Liber 4, Tractatus 1-2,7, ed. S. Pieperhoff (Hamburg: Meiner, 1987), lib. IV, tr. 1, c. 4, p. 23, 1. 2-p. 24, l. 39.

19 Berthold of Moosburg, Expositio super Elementationem theologicam Procli. Prologus, Propositiones 1-13, eds M.R. Pagnoni-Sturlese, L. Sturlese (Hamburg: Meiner, 1984), 9B, p. 170, l. 108-112: Dico autem a se ipso formaliter, non efficienter, quia causaliter effective nihil gignit se ipsum, ut sit, secundum Augustinum De Trinitate I cap. 1, cui alludit auctor De articulis fidei libro I prop. 3: "Nihil se ipsum composuit aut ad esse perduxit" et 8: "Nihil est causa sui", licet formaliter et procedat a se ipso et convertatur ad se ipsum. For further objections to the expression causa sui see Expositio, 7 E, p. 152, l. 502-508; Expositio, 18D, p. 53, l. 335-341; Expositio, 21B, p. 82, l. 212-219; Expositio, 35B, p. 4, l. 50-59; 38A, p. 27, l. 16-22; Expositio 150D, p. 121, 1. 76-78. Significantly, at Expositio super Elementationem theologicam Procli. Propositiones 35-65, ed. A. Sannino (Hamburg: Meiner, 2001), 52A, p. 119, l. 8o, where Berthold for once uses the expression non-critically, it is in the midst of a quotation from Albert the Great. 
$\mathrm{C}=$ Berthold of Moosburg, Expositio super Elementationem theologicam Procli. Propositiones 14-34, eds L. Sturlese, M.R. Pagnoni-Sturlese, B. Mojsisch (Hamburg: Meiner, 1986), 23B, p. 113, l. 65-p. 115, l. 107.

A

$1 \quad$ Primum etiam principium ad agendum omni modo liberum est.

2

Dicit enim Aristoteles in I Philosophiae Primae quod liberum dicimus, qui causa sui est'.

4 Cum ergo primum principium maxime sui causa sit in agendo, liberrimum in actione est nec tantum liberum, sed etiam libertati superpositum. Dominium enim habet in actione sua.
B

C

Liberum etiam est hic Dico autem sui ipsius primum principium tam existens, ut intelligatur esse in se quam in actione. liberum tam in se quam in actione sua.

In se quidem liberum In se quidem omne imparest, quia haec libertas ticipatum liberum est, quia non tollit necessitatem haec libertas non tollit immutabilitatis, quali- necessitatem immutabiliter primum principium tatis, qualiter omnis per se solum esse necessarium perfecta vel superperfecta supra probavimus, cum monas est immutabilis, cum haec necessitas maxime haec necessitas maxime faciat ipsum esse sui faciat ipsum esse sui gracausa in causando eo, tia eo, quod non conveniat quod non convenit nisi nisi prime et principaliter primae causae, enti, et hoc vel quod tale est simpliciter et absolute vel in respectu determinati ordinis per praemissam. 
(cont.)

$\begin{array}{lll}\text { A } & \text { B }\end{array}$

Dominus enim est pri-

mus omnium suorum

actuum. Si enim homo

dominus est suorum

actuum, cum causa

suorum actuum in

ipso est, multo magis

primus omnium domi-

nus est, qui sibi ipsi in

omni actione causa

est.

5 Adhuc autem, cum lib- sed tollit necessitatem Tollit autem haec libertas ertas quattuor modis dependentiae ad ali- necessitatem dependentiae dicatur, scilicet ab obli- quam causam, quae ad aliquam causam, quae gatione, a coactione, quattuor modis dicitur necessitas quattuor modis $\mathrm{ab}$ inevitabilitate et a secundum quattuor dicitur secundum quattuor necessitate positionis, genera causarum. genera causarum.

primum principium

omni modo liberum

est.

6 Libertas enim ab Est enim libertas ab Est enim necessitas obliobligatione est ad obligatione, quae obli- gationis, quae est vel per effectum causae mate- gatio est per materiam, materiam proprie dictam, rialis. Obligatio enim sicut homo obligatur sicut generatum obligatur per materiam est. per hoc, quod materia- per materiam ad corruptioSicut homo obliga- lis est, ad necessitatem nem, vel per materiam comtur ad necessitatem comedendi, dormiendi muniter dictam, qualis est comedendi, bibendi, et huiusmodi. Libertas corpus subiectum in caelo, dormiendi. A quibus ergo haec est per ad quod obligatur anima omnibus esset liber, si immaterialitatem. totalis, cum inter ea secunimmaterialis esset. dum quosdam sit mutua dependentia ita, quod, si unum eorum non esset, nec reliquum, vel communissime dictam quasi extenso nomine materiae, sicut 
(cont.)

A

B

C

subiecta intentionum in

aliis existentium, ad quae

obligantur in existentia

propter essentialem eorum

ad invicem dependentiam,

qua unum sine alio sub-

sistere non valeret. Et sic

solum illud, quod in se ipso

est sine dependentia ad

quodcumque materiale,

liberum est quoad iam dic-

tam libertatem, quae est

immunitas ab obligatione.

Et sic est quadruplex liber-

tas ab obligatione, scilicet

per immaterialitatem et

independentiam ad cor-

pus subiectum et in se ipso

esse et non in alio secun-

dum intentionem differ-

ente et sic esse illimitatum.

7 Necessitas autem Alia est libertas a coac-

Est secundo libertas a coac-

coactionis per causam

tione, quae coactio est

tione, quae est per causam

efficientem est. Sicut per causam efficientem,

efficientem seu producen-

necessitatem habet sicut vinculatus necesse

tem. Et hoc vel per causam

homo, quod combura- habet non ire, et liber- simpliciter omnium pro-

tur, si in igne ponatur; tas haec est per virtu- ductivam, quae est prime

vel ut non moveatur, si tis perfectionem, quae bonum, vel per eam, quae

vinculetur.

nihil extrinsecum potest

efficit aliquam multitu-

recipere.

dinem determinatam, ut sunt unitates, non ut sunt intra ordinem unialem conclusae - sic enim cadunt a dicta libertate -, sed ut sunt prime et principaliter entia ordinum suorum. 
(cont.)
A
B
C

8 Necessitas inevitabili- Tertia libertas est ab

Est et tertio libertas ab inevitatis a causa formali inevitabilitate, quae tabilitate, quae est per cauest. Sicut necesse habet inevitabilitas est per sam formalem.

homo non volare, quia formalem causam, sicut

pennas naturaliter homo necessario facit

non habet insitas; et humana propter for-

necesse habet homi- mam humanitatis,

nem esse et humana

facere propter formam

humanitatis.

et haec libertas est per Et haec radicatur in simplicsimplicitatem, qua itate, et hoc vel omnimoda aliquid formam non et absoluta vel in respectiva. habet partem sui, sed Sic enim quodlibet simest ipsa sua quiditas et plicium est sua libertas, qua est ipsa libertas et est, se toto est, quod est, et se quidquid habet. Illud toto agit, quod agit, et tamen enim operatur quidem agit libere, quia essentia sua per essentiam suam, est sua libertas.

quidquid agit, et tamen agit libere, quia sua essentia est sua libertas et libera voluntas, et hoc est in primo principio. Et ideo non est simile de hoc agente per essentiam et de naturalibus agentibus per essentiam suae formae, sicut ignis necessario comburit et similia.

10 Necessitas autem Quarta libertas est a Est quarto libertas a necespositionis secundum necessitate positionis, sitate positionis, quae est causam finalem est. quae necessitas est per per causam finalem, et quia Sicut necesse habet causam finalem, sicut imparticipata, sicut nec quis lucrari, si velit necesse est hunc secari, habent principium inquanditari; vel secari, si velit si debet curari. tum imparticipata, cum ipsa 
(cont.)

A

sanari. Posito enim

fine aliquo si debeat

aliquis consequi finem, necesse est studere ad ea quae sunt ad finem consequendum. Sicut Aristoteles dicit, quod 'ad habendum virtutem moralem necesse est habere prudentiam eo quod prudentia inquirit et eligit ea quae faciunt ad finem moralem virtutis, cum ipsa moralis virtus non nisi ut natura tendat in finem nihil eorum considerans quae faciunt ad sui finis consecutionem'.

11 Cum igitur primus Cum ergo primum ad nullam penitus principium ad nullam causam habeat depen- causam habeat dependentiam, constat, quod dentiam, patet, quod ab omni necessitate ipsum in se omnino liber est. liberum est.
12 Liberrimus ergo est primus tam in se quam in actione.
C

sint principia, sic etiam non habent finem, cum quodlibet sit finis, et hoc iterum vel simpliciter et absolute vel respectu determinatae maneriei.
Sicut autem omne imparticipatum habet libertatem in se, prout est sui ipsius ens et sui gratia, ita consimiliter habet libertatem in actione, cum agat per esse, et sic actio intra manens est unum cum essentia eorum. 
(cont.)
A
B
C

13 (1) Contra hoc tamen quidam nituntur opponere per ea quae antehabita sunt. Habitum est enim, quod primum necesse est esse omnino et omnimode. Et quod est omnimode necesse, nullo modo videtur esse liberum.

14 (2) Adhuc autem, habii tum est quod primum non nisi per essentiam agit, quia aliter non esset primum, si ageret vel per accidens vel per aliquid essentiae additum vel etiam per aliud. Quod autem per essentiam agit, de necessitate agit, sicut lux lucet per necessitatem essentiae.

15 (3) Adhuc autem, liberum est, in qua est agere et non agere. Si autem dicatur in primo esse agere et non agere, necesse est, ut concedatur primum aliter et aliter se habere. Hoc autem impossibile est, cum omnino sit impermutabile, ut in antehabitis probatum est. Ergo non est in ipso 
(cont.)

A

B

C

agere et non agere.

Necesse est ergo ipsum agere. Et sic necessitati subiacet et non libertati.

16 (4) Adhuc, nobilius est semper agere quam aliquando agere et aliquando non agere. Primo autem convenit semper agere, quia omne nobilius convenit ei. Cui autem convenit semper agere, de necessitate agit. Necessitati ergo subiacet et non libertati, ut videtur.

17 (5) Adhuc, in secundis quaecumque semper agunt et necessitatem habent in agendo, meliora sunt quam ea quae quandoque agunt et quandoque non agunt. Sicut caelestia meliora dicimus quam naturalia generabilia et corruptibilia et naturalia meliora fortuitis eo quod caelestia semper et de necessitate agunt, naturalia frequenter, fortuita autem raro. Videtur ergo, quod primi sit de necessitate agere et non de libertate. 
(cont.)
A
B
C

18 (1) Ad haec autem et similia facile responderi potest, scilicet quod primum omni modo necesse est esse. Sed non propter hoc tollitur ab eo libertas. Necessitas enim, quae est per dependentiam ad aliquam causam, tollitur a primo. Sed propter hoc non aufertur libertas, quin in ipso sit causa suae actionis.

19 (2) Similiter, per hoc quod dicitur, quod per essentiam agit, non potest probari, quod per necessitatem agat, nisi illa essentia subiaceat necessitati. Et similiter per sequens, quamvis sit simplicissimum, non concluditur, quod aliquam in agendo patiatur necessitatem. Simplicissimum enim liberrimum est inter omnia eo quod ipsum sibi ipsi causa est in omnibus. 
(cont.)

A B

20 (3) Adhuc autem, per Est etiam liberum

hoc quod dicitur, quod ad agendum et non

non sit in ipso agere et agendum ita, quod ad non agere, nihil proba- neutrum habet obliga-

tur. Hoc enim dupli- tionem nec impossibili-

citer dicitur. Non esse tatem ad alterum, sed

enim in aliquo agere et habens libertatem ad non agere potest esse utrumque non transpoper obligationem ad nitur de uno in alterum, unum et impossibili- quia melius est esse tatem ad alterum. Alio unum quam alterum, modo potest esse per sicut "homo sanctus in libertatem ad unum et sapientia manet sicut ad alterum. Sed quia sol", Eccli. 27. Cum melius est esse unum tamen liber sit ad hoc et quam alterum, prop- ad oppositum, sic enim ter hoc non transponi- in primo est agere et non tur de uno in alterum. agere, sed non potest Sicut in casto est caste non agere, quia melius agere et non caste, et est emittere bonitates in liberali dare et non quam invidiose retinere dare. Sed quia melius est caste agere et liberaliter dare quam non caste agere et avare retinere, ideo non transponitur castus et liberalis in oppositum suae actionis. Et sic agere et non agere quidem est in primo, sed non potest non agere, quia melius est emittere bonitates quam retinere, et minimum inconveniens in primo impossibile est. 
(cont.)
A
B
C

21 (4) Ex hoc etiam patet responsio ad sequens: Tali enim modo semper agere nobilissimum est et multo nobilius quam aliquando agere et aliquando non agere. Sicut dicit Messahalla, quod motus caeli motus sapientis est eo quod sapientis uno modo est agere et semper et non per inconstantiam aliquando agere et aliquando non agere vel sic et aliter agere. Tali enim modo agit, quod per diversa disponitur. Quod non convenit primo.

22 (5) Hoc etiam modo quaecumque secundorum semper agunt, ad intelligentiae actionem referuntur, quae uno et eodem se habet modo et uno et eodem modo desideratur a mobili. Et propter hoc illa nobiliora sunt quam ea quae frequenter vel raro agunt et a diversis ad diversa disponuntur. Non tamen propter hoc intelligentia alicui subiacet necessitati. 
(cont.)
A
B
C

23 Ex omnibus his colligitur, quod primum

liberrimum est in omnibus suis tam in agendo quam in aliis eo quod ad nihil penitus habet dependentiam et sibi ipsi sufficiens causa est ad omnia et in omnibus.

24 Propter quod etiam propter quod etiam Dico autem ipsum imparmeliores Peripatetico- Avicenna et alii meliores ticipatum habere a se rum primum dixerunt Peripateticorum dicunt ipso, scilicet formaliter, esse largissimum primum esse largissi- et in se ipso essentialiter secundum illam lar- mum secundum illam superplenitudinem. gitatis speciem, quae speciem largitatis, quae magnificentia vocatur. est magnificentia, quia Hoc enim est, quando semper fluit optimis et aliquis fluit optimis non deficit eo, quod sibi et non deficit propter sufficit et omnibus aliis. hoc quod in optimis in seipso sufficientiam habet, per quam sibi et omnibus aliis sufficit abundanter.

Primum ergo in hoc agereliberrimum est tam propter libertatem iam dictam quam etiam propter hoc, quod, ut dicit Philosophus in I Metaphysicae, liberum dicimus, quod causa sui est. 
(cont.)

A

B

C

26

Cum ergo primum
principium maxime
sui causa sit in agendo,
liberrimum est in
actione et per conse-
quens dominium habet
in actione sua, quia qui-
libet est dominus suo-
rum actuum, cum causa
ipsorum in ipso est.

\section{Bibliography}

\section{Primary Sources}

Albert the Great, In II Sententiarum, ed. A. Borgnet, vol. 27, Paris, Vivès, 1894.

Albert the Great, Metaphysica, ed. B. Geyer, Münster i.W., Aschendorff, 196o-1964.

Albert the Great, Summa theologiae sive de mirabili scientia Dei. Libri I, pars I. Quaestiones 1-5oA, ed. D. Siedler, Münster i.W., Aschendorff, 1978.

Albert the Great, De causis et processu universitatis a prima causa, ed. W. Fauser, Münster i.W., Aschendorff, 1993.

Albert the Great, De homine, eds H. Anzulewicz, J. Söder, Münster i.W., Aschendorff, 2008.

Anselm, Cur Deus homo, ed. F.S. Schmitt, Edinburgh, Thomas Nelson and Sons, 1946 (vol. 2), p. 37-133.

Berthold of Moosburg, Expositio super Elementationem theologicam Procli. Prologus, Propositiones 1-13, eds M.R. Pagnoni-Sturlese, L. Sturlese, Hamburg, Meiner, 1984.

Berthold of Moosburg, Expositio super Elementationem theologicam Procli.Propositiones 14-34, eds L. Sturlese, M.R. Pagnoni-Sturlese, B. Mojsisch, Hamburg, Meiner, 1986.

Berthold of Moosburg, Expositio super Elementationem theologicam Procli. Propositiones 35-65, ed. A. Sannino, Hamburg, Meiner, 2001.

Berthold of Moosburg, Expositio super Elementationem theologicam Procli.Propositiones 160-183, eds U.R. Jeck, I.J. Tautz, Hamburg, Meiner, 2003.

Proclus, The Elements of Theology, ed. E.R. Dodds, Oxford, Clarendon Press, $1963^{2}$. 
Ulrich of Strassburg, De summo bono. Liber 4, Tractatus 1-2,7, ed. S. Pieperhoff, Hamburg, Meiner, 1987.

\section{Secondary Sources}

Anzulewicz, H., "Das Phänomen des Schicksals und die Freiheit des Menschen nach Albertus Magnus," in J. Aertsen, K. Emery Jr., A. Speer (eds), Nach der Verurteilung von 1277. Philosophie und Theologie an der Universität von Paris im letzten Viertel des 13. Jahrhunderts. Studien und Texte, Berlin, De Gruyter, 2001, p. 507-534.

Beierwaltes, W., "Pronoia und Freiheit in der Philosophie des Proklos," in Freiburger Zeitschrift für Philosophie und Theologie 24(1977), p. 88-111.

Beierwaltes, W., "Proklos' Theorie des Authypostaton und seine Kritik an Plotins Konzept einer causa sui," in Das wahre Selbst, Frankfurt am Main, Klostermann, 2001, p. 16o-181.

Goris, W., "Metaphysik der Freiheit," in J. Müller, Ch. Rode (eds), Freiheit und Geschichte. Festschrift für Theo Kobusch zum 7o. Geburtstag, Münster i.W., Aschendorff, 2018, p. 229-250.

Goris, W., "Die Freiheit und das Gute," in C. Böhr (ed.), Metaphysik. Von einem unabweislichen Bedürfnis der menschlichen Vernunft. Rémi Brague zu Ehren, Wiesbaden, Springer VS 2020, p. 373-39o.

Halfwassen, J., "Freiheit als Transzendenz. Zur Freiheit des Absoluten bei Schelling und Plotin," in J.-M. Narbonne, A. Reckermann (eds), Pensées de l'Un dans l'histoire de la philosophie. Études en hommage au Professeur Werner Beierwaltes, Paris, Vrin, 2004, p. 459-481.

Kobusch, Th., "Bedingte Selbstverursachung. Zu einem Grundmotiv der neuplatonischen Tradition," in Th. Kobusch, B. Mojsisch, O.F. Summerell (eds), Selbst - Singularität - Subjektivität. Vom Neuplatonismus zum Deutschen Idealismus, Amsterdam / Philadelphia, Grüner, 2002, p. 155-173.

Krijnen, Ch., "Die Wirklichkeit der Freiheit begreifen. Hegels Begriff von Sittlichkeit als Voraussetzung der Sittlichkeitskonzeption Kants," in Folia Philosophica 39(2018), p. $37-144$.

Miteva, E., "I Want to Break Free. Albert the Great's Naturalistic Account of Freedom of Choice and its Limitations," in Bochumer Philosophisches Jahrbuch für Antike und Mittelalter 21(2018), p. 11-28.

Porro, P. "Res a reor, reris / res a ratitudine. Autour d'Henri de Gand", in I. Atucha, D. Calma, C. König-Pralong, I. Zavattero (eds), Mots médiévaux offerts à Ruedi Imbach, Porto / Turnhout, Fédération Internationale des Instituts d'Études Médiévales, 2011, p. 617-628. 